\title{
Carabapenem-resistant bacteria a looming threat in Canada
}

Previously published at www.cmaj.ca

$\mathrm{M}$ icrobiologists are urging that Canada ramp up its surveillance of another strain of bacteria - carbapenem-resistant Klebsiella pneumoniae (KPC) - by screening Canadians who've been hospitalized in the United States, Israel and Greece, and handling them with special care.

So-called "snowbirds," (Canadians who winter in Florida), in particular, pose a serious problem, the experts say. But the Public Health Agency of Canada (PHAC) says the cost of additional screening measures isn't yet justified on a nationwide basis.

The warnings about KPC, which has been identified in at least three Canadian patients, follow on the heels of recent calls by the World Health Organization to bolster screening and surveillance of a drug-resistant bacteria carrying the gene for New Delhi metallo-beta-lactamase-1 (www.cmaj.ca/cgi/doi/10.1503/cmaj.109 -3675). Unlike the New Delhi bug, though, KPC is raising worries about all forms of, not just medical, tourism, largely because it is widespread in many cities in the United States, is associated with elevated patient mortality rates, and poses therapeutic challenges (www.cmaj .ca/cgi/doi/10.1503/cmaj.090167).

First identified a decade ago, KPC is now found in an estimated $30 \%$ of all laboratory samples taken from patients in New York City hospitals, says Robert Bonomo, a microbiologist at Louis Stokes Cleveland Veterans Affairs Medical Centre, in Cleveland, Ohio. "It's a real clinical problem in certain areas," he says, noting that several studies have identified patients in long-term care facilities and hospitals as being at risk ( $J$ Antimicrob Chemother 2010;65:1807-18). "The genetic elements KPC is carried in have become very mobile throughout parts of the Middle East and the US Northeast. And early reports suggest a higher attributable mortality."

Such concerns have prompted public health authorities in Europe to implement nationwide KPC screening of patients previously admitted to hospitals in areas where it is endemic, says Patrice

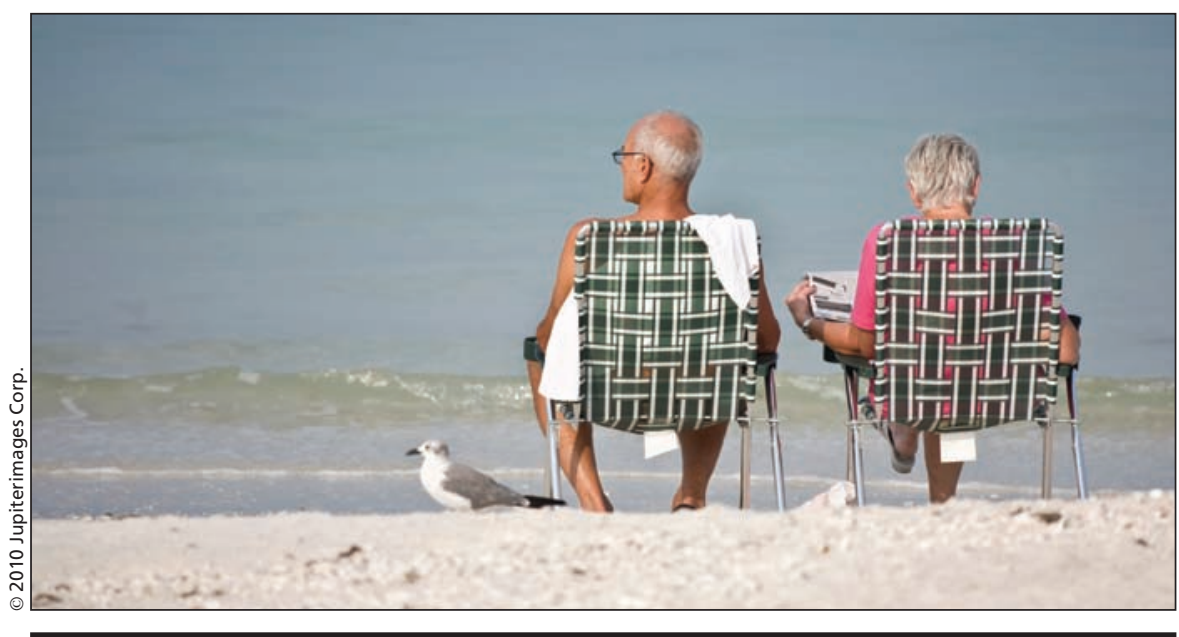

Elderly Canadians who spend their winters in Florida face and pose the most serious risk because they are more likely to find themselves in United States hospitals, in which carbapenem-resistant Klebsiella pneumoniae is rampant.

Nordmann, director of INSERM 914, France's national antibiotic resistance laboratory. He recommends that Canadian authorities follow the European lead and begin screening "all patients admitted abroad for all carbapenemases."

Concern about KPC also prompted the 2009 creation of a one-year surveillance project in 12 Canadian hospitals, says Dr. Howard Njoo, PHAC's director general for communicable diseases and infection control. That has since been extended to August 2011 and 30 hospitals, but early indications are that KPC levels "are not a cause for alarm."

Others, though, are worried, including Marc Desjardins, clinical microbiologist at the Ottawa Hospital in Ontario, whose encounter with three KPC-infected patients in 2007 convinced him that widespread prevalence in the US poses a cross-border threat (J Clin Microbiol 2009;47:920-2).

"They are fairly easy to miss and it can be quickly passed along if you don't control it."

Clinicians should be braced for total antibiotic resistance and subsequent treatment failure, Desjardins adds. In one patient, "the strain was resistant to everything. Nothing worked. She died of it."

Canada has avoided US-style levels of KPC because it has more proactive infection control strategies but that's no reason for complacency, Desjardins adds, urging consistent use of hightech PCR-based genetic testing techniques in screening for carbapenumresistant bacterial expressions, which are "evolving rapidly."

Desjardins also worries that the era of antibiotic-based infection control is ending. "The organisms are developing multiple resistance mechanisms. They are hyper-producing some of these enzymes."

He recommends "targeted surveillance based on travel." That's echoed by Johann Pitout, a University of Calgary, Alberta, microbiologist who urges that all patients who were admitted to hospitals in the US, Greece, Israel be screened for KPC, while those who were admitted to hospitals in South Asia should be screened for both KPC and New Delhi metallo-betalactamase-1.

Elderly Canadians who spend their winters in Florida face and pose the most serious risk, Pitout adds. "The snowbirds are the biggest issue. This is definitely a growing phenomenon.

Njoo, though, says the "cost benefit" of a French-style national directive to screen all patients who had been admitted to foreign hospitals is not justified by the number of cases of carbapenum resistance identified to date. - Paul Christopher Webster, Toronto, Ont.

DOI:10.1503/cmaj.109-3695 